\title{
A demonstration of cone function plasticity after gene therapy in achromatopsia
}

\author{
Mahtab Farahbakhsh"1, Elaine J. Anderson*1,2,7 ${ }^{*}$ Andy Rider ${ }^{1}$, John A. Greenwood ${ }^{3}$, Nashila \\ Hirji ${ }^{1,6}$, Serena Zaman ${ }^{1,6}$, Pete R. Jones ${ }^{1,4}$, D. Samuel Schwarzkopf ${ }^{3,5}$, Geraint Rees ${ }^{2,7}$, \\ Michel Michaelides ${ }^{* * 1,6}$, Tessa M. Dekker**1,3
}

* equal contribution first authorship, ${ }^{* *}$ equal contribution last authorship

Affiliations:

1. UCL Institute of Ophthalmology, University College London, UK.

2. UCL Institute of Cognitive Neuroscience, University College London, UK.

3. Experimental Psychology, University College London, UK.

4. School of Ophthalmology, City University, London, UK.

5. School of Optometry \& Vision Science, University of Auckland, NZ.

6. Moorfields Eye Hospital, London, UK

\begin{abstract}
Achromatopsia (ACHM) is an inherited retinal disease characterised by complete loss of cone photoreceptor function from birth. In recent years, gene therapies have successfully been used to induce signal processing in dormant cones in animal models of $\mathrm{ACHM}$, with greater functional benefits for younger animals. With several completed or on-going clinical trials of gene therapy for ACHM, preliminary evidence suggests that effects on visual function in adults with ACHM may be subtle. Given the known constraints of age on neural plasticity, it is possible that gene therapy earlier in life will have a greater impact. Sensitive, child-friendly tests of cone function are therefore needed to facilitate the optimisation of these treatment strategies. Here, we present a new method that leverages a multimodal approach, linking psychophysical estimates of cone function to cone-mediated signals in visual cortex, measured using fMRI. In a case study of two children with ACHM undergoing gene therapy, we find individual differences in recovery of cone function over time, with one child demonstrating strong concurrent evidence of improved cone function, and retinotopically organised responses in visual cortex to cone-selective stimuli. Integrated $\mathrm{fMRI}$ and psychophysical measures may provide insight into the utility of new sight-rescuing

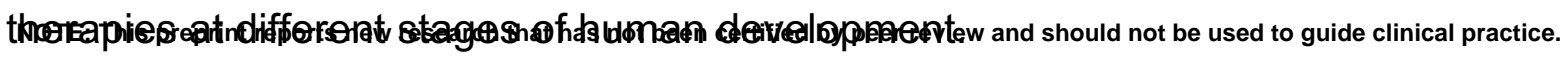


medRxiv preprint doi: https://doi.org/10.1101/2020.12.16.20246710; this version posted December 23, 2020. The copyright holder for this preprint (which was not certified by peer review) is the author/funder, who has granted medRxiv a license to display the preprint in

\section{Introduction}

Achromatopsia $(\mathrm{ACHM})$ is a non-progressive recessively inherited retinal disorder in which disease-causing sequence variants in a single gene prevents cone photoreceptors from signalling. ACHM occurs in 1:30,000 births (Aboshiha et al., 2014; Johnson et al., 2004), with the most prevalent variants located in two genes, CNGA3 ( $30 \%$ of European and US cases) and CNGB3 ( $50 \%$ of cases) (Kohl et al., 2005). These genes encode the $\alpha$ and $\beta$ subunits of the cone cyclic nucleotide-gated (CNG) channel respectively, both essential for the cone phototransduction cascade. As a result, vision in patients with ACHM is rod-dominated, and characterised by low acuity (6/36-6/60), insensitivity to chromatic contrasts, day-blindness, photophobia, and involuntary oscillation of the eyes (pendular nystagmus) (Hirji, Aboshiha, et al., 2018). Practically, patients have difficulty reading and recognising faces, do not perceive colour, and may wear sunglasses or darkened lenses to reduce discomfort from light exposure.

The retinal integrity of the two commonest forms of $A C H M$ (mutations in CNGA3 and CNGB3) have been studied in great detail (cross-sectionally and longitudinally), both with high-resolution optical coherence tomography to investigate retinal lamination and also cellular imaging to directly probe the photoreceptor mosaic in vivo (Dubis et al., 2014; Georgiou et al., 2019; Hirji, Aboshiha, et al., 2018; Hirji, Georgiou, et al., 2018). These studies have identified that although there is a marked reduction in cone cell density, all patients have residual cone cells that could be targeted for rescue, albeit with significant inter-subject variability in number.

$\mathrm{ACHM}$ is a promising candidate for genetic therapy, given its well understood genetic aetiology, availability of animal models (including naturally occurring models), the presence of potentially viable cone cells, and the accessibility and low immune response of the retina to surgical intervention. The feasibility of using gene therapy safely to successfully treat inherited eye disease, was demonstrated recently with the first FDA and EMA approved gene therapy for RPE65-associated retinal dystrophy, Leber's Congenital Amaurosis, a severe early-onset blinding disease (Ciulla et al., 2020). There are currently three phase I/II gene therapy trials for CNGA3-associated ACHM (NCT03758404, NCT02935517, and NCT02610582), and two phase I/II gene therapy trials for CNGB3-ACHM (NCT03001310 and NCT02599922). 
medRxiv preprint doi: https://doi.org/10.1101/2020.12.16.20246710; this version posted December 23, 2020. The copyright holder for this preprint (which was not certified by peer review) is the author/funder, who has granted medRxiv a license to display the preprint in It is made available under a CC-BY-NC-ND 4.0 International license .

Recently, the first published data of a gene therapy clinical trial (NCT02610582) in 9 treated adults with CNGA3-associated $\mathrm{ACHM}$ revealed variable but modest degrees of improvement in visual acuity, contrast sensitivity, flicker fusion, and colour thresholds after intervention (Fischer et al., 2020). Effects were marginally greater in the treated eye than untreated eye for most measures. This makes it less likely that changes reflect test-retest improvements, although placebo-controlled studies with larger participant numbers are needed to evaluate treatment efficacy. These first results are promising, suggesting that gene therapy may safely be used to induce cone function in adults with ACHM. However, in animal models of ACHM, gene therapy had the most substantial functional benefits in younger animals (Carvalho et al., 2011). Patient age may therefore, in part, reduce the scope for functional improvements in gene therapy with adults (e.g., Fischer et al., 2020). Functional gains for the mature visual system may be limited by reduced retinocortical plasticity: with life-long absence of cone function, rods may appropriate neural resources normally reserved for cones. In the case of amblyopia, it is known that the effects of neural competition on brain structure and function become more entrenched with age (Holmes et al., 2011; Kiorpes, 2019). Gene therapy benefits may therefore be increased by exploiting the inherent plasticity of the developing brain. However, effectively testing this requires sensitive measures of neural function that can be used with young patients, often with shorter attention spans, severely reduced visual acuity, and poor fixation - and these are currently lacking.

Here, we leverage a multi-modal approach that tests the neurofunctional impact of gene therapy in childhood, linking changes in psychophysical estimates of cone sensitivity to functional Magnetic Resonance Imaging (fMRI) measures of cone signal processing in the developing visual cortex. We are currently evaluating longitudinal use of this approach in children with ACHM (CNGA3- or CNGB3-associated) enrolled in ongoing gene therapy trials (NCT03758404 and NCT03001310), in a standalone MRI study alongside the main trail

As data collection is still ongoing, with treatment conditions and outcomes yet to be disclosed, we present interim measures in 2 paediatric patients of similar age each tested before, and $\sim 6$ months after treatment (patient T1 and T2, with CNGB3 
medRxiv preprint doi: https://doi.org/10.1101/2020.12.16.20246710; this version posted December 23,2020 . The copyright holder for this
preprint (which was not certified by peer review) is the author/funder, who has granted medRxiv a license to display the preprint in It is made available under a CC-BY-NC-ND 4.0 International license .

and CNGA3 variants respectively). These patients were selected for this report based on their high data quality and close match in age (both >9 years old - exact age not provided for confidentiality reasons), and because, whilst only two examples, their data allows us to present the range of outcomes observed with the multi-modal approach after treatment thus far. Results are contextualised against data from 10 untreated patients with $\mathrm{ACHM}$, and 28 normally sighted control participants. Longitudinal data of the full dataset of treated children tested will be reported after trial completion.

\section{Results}

We present data from two patients with AHCM who underwent a gene therapy currently under trial. One patient demonstrated evidence of therapy-induced improvement in cone function 6 months post treatment. Before treatment, this patient's psychophysical and functional brain imaging measures resembled those of 10 other untreated achromatopsia patients. Measurements after treatment, resembled those obtained from 25 normal sighted controls, with a pattern unlikely to be explained by measurement confounds or false positives. Another patient with $\mathrm{ACHM}$ of matched age undergoing gene therapy, demonstrated no such improvement, suggesting this multimodal approach can effectively track individual differences in outcome.

\section{Behavioural Psychophysics}

To test cone sensitivity psychophysically, we used a "silent substitution" approach to generate chromatic pairs with a range of cone photoreceptor contrasts, varying from high to low cone contrast. The red, green, and blue phosphor values of each chromatic pair were selected to increase or decrease the response of long (L) and middle (M) wavelength sensitive cone photoreceptors, whilst keeping rod photoreceptors silent (see Methods). Screen luminance was maintained within the cone-sensitive range throughout $\left(0.6\right.$ to $\left.13 \mathrm{~cd} / \mathrm{m}^{2}\right)$. Stimulus validation (See Supplementary Materials 1), however, revealed that the light spectra emitted by high contrast chromatic pairs induced some rod-contrast, likely due to measurement noise and imperfect correction for the screen's non-canonical gamma function. In line with this, some higher contrast chromatic pairs were detected by AHCM patients, presumably using rod-based vision. This made it crucial to establish before treatment, 
medRxiv preprint doi: https://doi.org/10.1101/2020.12.16.20246710; this version posted December 23, 2020. The copyright holder for this preprint (which was not certified by peer review) is the author/funder, who has granted medRxiv a license to display the preprint in It is made available under a CC-BY-NC-ND 4.0 International license .

which contrast levels were reliably below the detection threshold of patients with ACHM. Improved discrimination beyond this pre-treatment baseline, provides evidence for induced cone function after gene therapy.

We embedded chromatic pairs in a 4AFC target localisation task (Figure $1 \mathrm{~A} \& 1 \mathrm{C})$, as well as in a $2 \mathrm{AFC}$ movement discrimination task with the population receptive field ( $p R F)$ mapping stimuli (Figure 1B\&1D). The latter test was included to ensure that psychophysics measurements were representative of the circumstances under which fMRI cone sensitivity measures were acquired. In both cases, a 1-up/1down staircase was used (converging on $50 \%$ correct) to identify the lowest stimulus contrast that patients with $\mathrm{ACHM}$ could detect. Note that even the lowest cone contrast presented (Figure $1 \mathrm{~A}$ ) is above threshold and effortlessly visible to a normal-sighted individual, but invisible to those with untreated ACHM. Despite different chance levels and tasks, the two psychophysical measures showed good correspondence before treatment (Supplementary Materials 1 Figure S1b\&S1c), suggesting they reliably captured the smallest noticeable rod photoreceptor contrast.
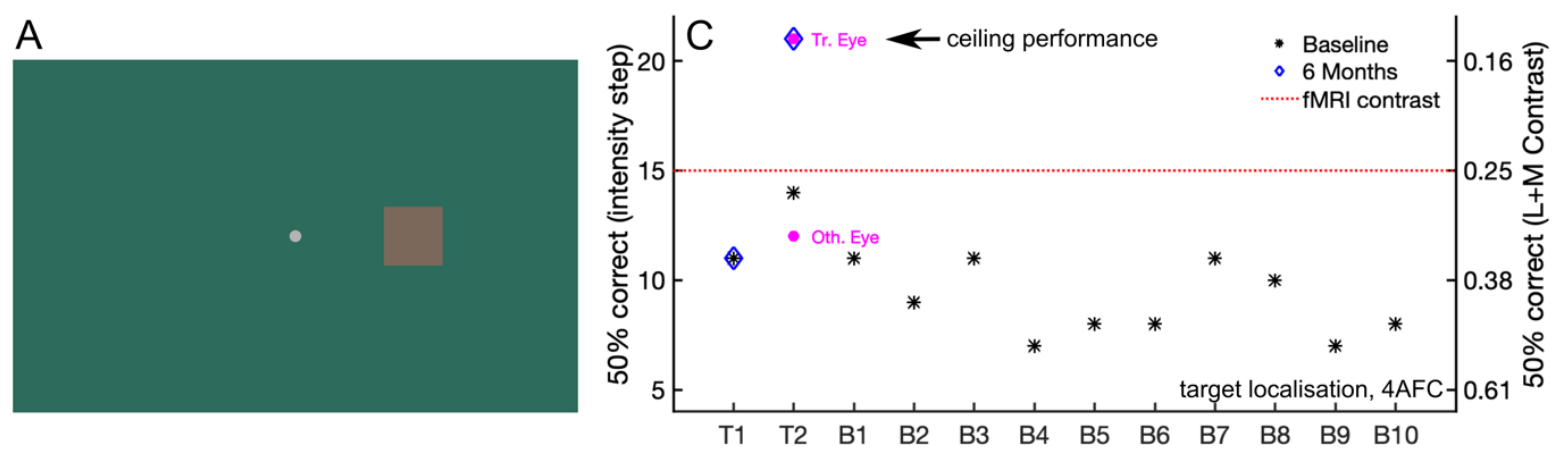

B

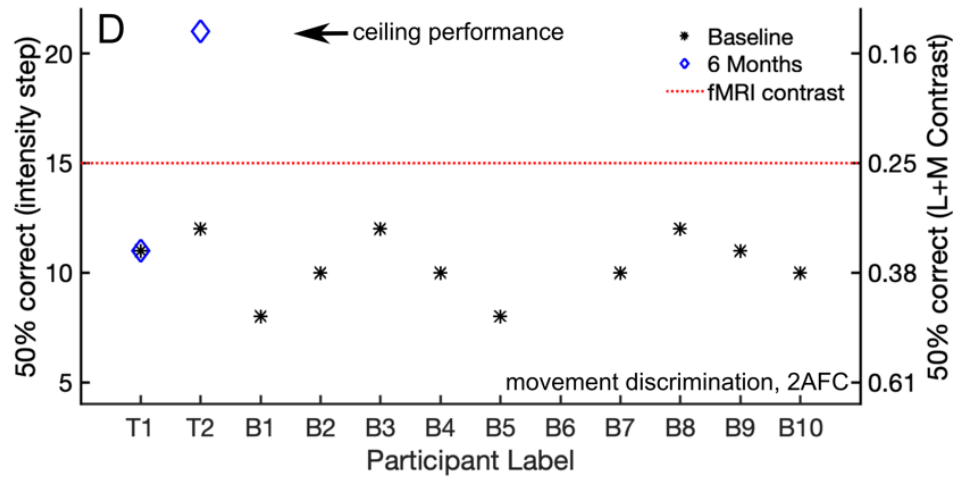

Figure 1: A) Psychophysics outside the scanner: example of the lowest cone-selective contrast tested psychophysically, embedded in $4 A F C$ target localisation tasks. Participants judged the position of a target (size $3^{\circ}$ ), presented $6^{\circ}$ to the left, right, above, or below centre, with unlimited time to search and uncontrolled gaze. Note that stimulus appearance is screen-dependent. B) pRF mapping stimulus 
medRxiv preprint doi: https://doi.org/10.1101/2020.12.16.20246710; this version posted December 23, 2020. The copyright holder for this preprint (which was not certified by peer review) is the author/funder, who has granted medRxiv a license to display the preprint in

It is made available under a CC-BY-NC-ND 4.0 International license .

presented inside the scanner: combined ring/wedge stimulus (max eccentricity $8.6 \%$ ), depicted at the cone-selective contrast shown in the scanner (red dotted line, C\&D). Participants detected target dimming events at fixation. After scanning, in a 2AFC psychophysics task, participants discriminated ring movement (inward/outward). Note that stimulus appearance is screen-dependent. C) Binocular 4AFC contrast discrimination thresholds (50\% correct) for children with ACHM. Left y-axis indicates contrast detection thresholds in units of staircase step with decreasing stimulus intensity (1=highest contrast, $21=$ =lowest contrast), with the right $y$-axis indicating the corresponding $L+M$ cone Michelson contrasts (see Supplementary Material 1 for details). Stars indicate baseline measures for 12 untreated children with ACHM. Higher-contrast stimuli were above threshold for untreated patients with ACHM, likely due to imperfect rod silencing (Supplementary Materials 1 Figure S1a). Follow up measures $~ 6$ months after treatment, are shown for treated case study patients T1 and T2 (blue diamonds). 6-month measures of patient T2 were repeated monocularly for the treated and other, untreated eye (magenta circles). D) As in $C$ but showing binocular contrast discrimination thresholds (at $50 \%$ correct) for the $2 A F C$ task performed in the scanner.

Figure 1C \& 1D present binocular baseline thresholds for 12 untreated children with ACHM (black stars). For case study patients $\mathrm{T} 1$ and $\mathrm{T} 2$, we also present longitudinal measures collected $\sim 6$ months after gene therapy (blue diamonds). Before treatment, both patients' discrimination thresholds were in the range expected of children with $\mathrm{ACHM}$. However, approximately 6 months after treatment, although the discrimination thresholds for patient T1 had remained unchanged, T2's performance had improved to ceiling level - exceeding both their pre-treatment performance and the baseline measures of 10 other untreated patients on both tasks (see also Supplementary Materials 1 Figure S1b\&c). Critically, this improvement was specific to the treated eye; T2's monocular cone contrast discrimination was at ceiling for the eye that received gene therapy treatment, but remained at pre-treatment levels for the other eye (Figure 1C).

\section{Retinotopic Mapping fMRI}

After quantifying individual differences in cone function psychophysically, we tested for concurrent evidence of cone-mediated signal processing in visual cortex. During $\mathrm{fMRI}$, we presented participants in the scanner with one fixed cone contrast level (Figure 1B), embedded in a ring and wedge travelling checkerboard stimulus. Psychophysical measures and subjective reports confirmed that all 10 untreated patients with $\mathrm{ACHM}$ were unable to perceive this stimulus (Figures 1D, Supplementary Materials 1 Figures S1B \& S1C). This confirms these stimuli were accurately calibrated 
medRxiv preprint doi: https://doi.org/10.1101/2020.12.16.20246710; this version posted December 23, 2020. The copyright holder for this preprint (which was not certified by peer review) is the author/funder, who has granted medRxiv a license to display the preprint in

It is made available under a CC-BY-NC-ND 4.0 International license.

to selectively stimulate cone photoreceptors whilst leaving the rods silent. We then used a population receptive field ( $\mathrm{pRF}$ ) mapping approach (Dumoulin \& Wandell, 2008) to test for any cone-mediated responses in visual cortex (see methods).

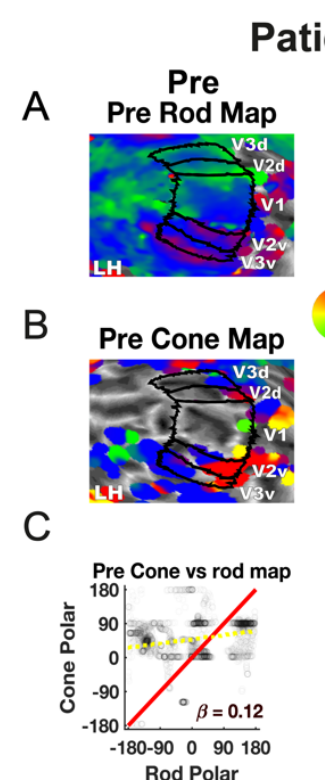

Rod Polar
Patient T1
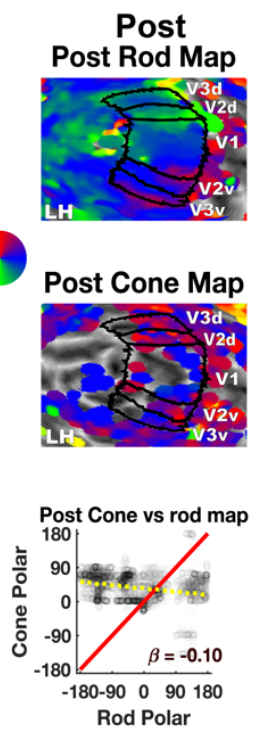

Patient T2
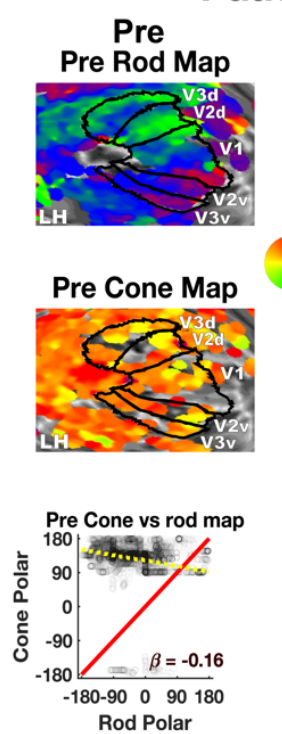

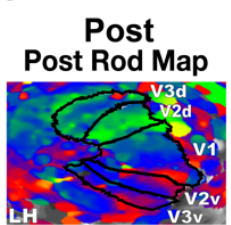

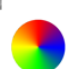
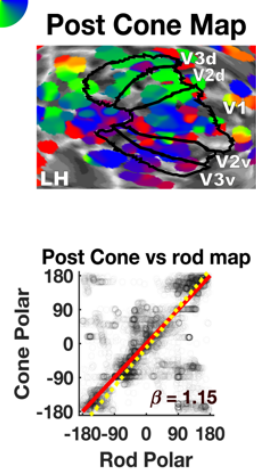

Control
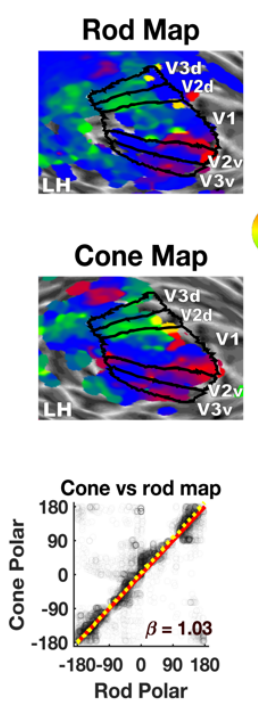

Figure 2. Cone-mediated versus rod-mediated polar angle map organisation in areas V1, V2, and V3, before and after gene therapy in 2 patients, and an age-matched control participant. A) Rod-mediated polar angle estimates are projected onto the left hemisphere cortical surface, inflated to a sphere and zoomed in on. V1, V2, and V3 labels are drawn based on individual polar maps obtained in luminance contrast pRF scans. B) Cone-mediated polar angle map projected on the same hemisphere C) Rodmediated polar angle values ( $x$-axis) from the left and right V1, V2, and V3, scattered against conemediated polar angle values (y-axis). Red identity line indicates perfect correspondence between the rod and cone map. Yellow dotted line indicates the orthogonal linear regression fit, with slope $\beta_{\text {orth. }}$

We reasoned that the transmission of retinal responses to upstream visual cortex areas may be weak, if evoked for the first time in life following gene therapy. Therefore, to distinguish between noise and retinotopically organised signal, we compared the retinotopic structure of cone-mediated pRF maps with a rod-mediated retinotopic map from the same individual. To match rod-mediated maps as closely as possible across participants with and without functioning cones, we used stimuli designed to activate rods whilst keeping $\mathrm{L}$ - and $\mathrm{M}$-cone photoreceptors silent. We refer to this map as 'rod-mediated', although S-cone signals may also contribute to these maps in control individuals (see Supplementary Materials 2). In normal visual development, polar angle tuning is spatially co-located for rod- and cone-mediated 
medRxiv preprint doi: https://doi.org/10.1101/2020.12.16.20246710; this version posted December 23, 2020. The copyright holder for this preprint (which was not certified by peer review) is the author/funder, who has granted medRxiv a license to display the preprint in It is made available under a CC-BY-NC-ND 4.0 International license .

inputs in visual cortex, except around the foveal confluence, where rod-driven responses are lacking due to the absence of rod-photoreceptors in the retinal fovea (Barton \& Brewer, 2015). For observers with healthy cone photoreceptors, we therefore expected high spatial correspondence between the cone- and rod-mediated polar angle maps. For untreated children with ACHM we expected no cone-mediated retinotopy, so there should be poor correspondence with the rod-mediated map, with the emergence of well-aligned polar angle cone-mediated map structure after treatment providing evidence for recovery of cone function. To maximise power to detect even weak cone-mediated signals in visual cortex, we did not apply a threshold to the pRF model goodness-of-fit when comparing cone- and rod-mediated maps.

\section{Cone-mediated Retinotopic Map Structure}

Both patients with ACHM showed clearly visible retinotopic organisation in the rod-mediated (unthresholded) maps, visualised in Figure 2A, with polar angle maps that closely resembled those of the example control participant maps in overall layout. Note that map organisation is highly consistent within individuals. Before treatment, cone-selective pRF mapping evoked no visible retinotopic map in either patient with ACHM, as expected (Figure 2B). After treatment, patient T1 still showed no discernible cone-mediated map, but patient T2 now demonstrated upper (red) and lower (green) visual field representations in expected cortex locations, aligned with the upper and lower fields in the rod-mediated map.

To quantify polar angle correspondence between maps, we plotted values from visual areas V1-V3 from the cone-mediated map against those from the rod-mediated map (Figure 2C). Close correspondence between maps in polar angle layout, is reflected in the clustering of data along the identity line. To test for presence versus absence of correspondence, we compared two orthogonal regression models, one following the identity line (slope $\beta=1$, intercept $=0$ ) and the other a horizontal line with a free parameter intercept to model relationship absence. To compute the strength of evidence for the correspondence model, we calculated the Akaike Weight (Burnham, \& Anderson, 2002; Wagenmakers et al., 2004). For the control participant with normal cone function, there was strong evidence for correspondence across the cone and rod-mediated polar-angle maps $\left(\mathrm{AIC}_{\beta=1}\right.$ weight $\left.\approx 1\right)$, with clustering of data along the 
medRxiv preprint doi: https://doi.org/10.1101/2020.12.16.20246710; this version posted December 23, 2020. The copyright holder for this preprint (which was not certified by peer review) is the author/funder, who has granted medRxiv a license to display the preprint in It is made available under a CC-BY-NC-ND 4.0 International license .

identity line (orthogonal regression slope $\beta_{0 \text { orth,95cl }}=1.02-1.04$ ) and high circular correlation between maps (CorrCoef Fisher-Lee $=0.75, p<0.01$; Pewsey et al., 2013) (Figure $2 \mathrm{C}$, right). Before treatment, there was poor spatial correspondence between cone- and rod-mediated polar angle maps for both patients with ACHM (T1\&T2 AIC $\beta=1$ weights $\approx 0$ ), with low correlations $\left(\right.$ CorrCoef $_{\text {Fisher-Lee }} \mathrm{T} 1=-0.05, p<0.01$, CorrCoef $f_{\text {Fisher- }}$ Lee T2 $=-0.12, \mathrm{p}<0.01)$ and flat regression slopes $\left(\beta_{\text {orth,95Cl T1 }}=0.11-1.14 ; \beta_{\text {orth,95CI T2 }}\right.$ $=-0.19:-0.14)$. This dichotomy was replicated across 25 normally sighted controls and 10 untreated patients (Supplementary Materials 3 Figure S3a). Note that the narrow range of cone-mediated polar angles in untreated patients, likely reflect subtle biases in the pRF fitting process (related to the coarse-fit grid-search), uncovered by the low goodness-of-fit threshold rather than cone function for select visual field locations.

6 months after treatment, patient T1's cone-mediated map still showed little correspondence with the retinotopic rod-mediated map (CorrCoef Fisher-Lee $=-0.12$, $\beta_{\text {orth, } 95 \mathrm{Cl}}=-0.11:-0.9, \quad \mathrm{AlC}_{\beta=1}$ weight $\approx 0$ ). In patient $\mathrm{T} 2$, however, a promising correspondence between these maps had emerged, albeit with a noisier relationship than in controls (CorrCoef Fisher-Lee $=0.3, p<0.01, \beta_{\text {orth }, 95 \mathrm{Cl}}=1.13: 1.16, \mathrm{AlC}_{\beta=1}$ weight $\approx 1$ ). These results were replicated using the $X$ and $Y p R F$ position estimates that polar angle is computed from, so these results are not an artefact of polar angle circularity (Supplementary Materials 3 Figure S3b). While we also noted a change in the conemediated eccentricity map of patient T2 after treatment, correspondence with the rodmediated map was less clear than for the polar angle measure (Supplementary Materials 3 Figure S3c). It is possible that cone-mediated eccentricity map organisation may be more affected by life-long function loss, but more data from additional participants is needed to test this.

\section{Cone-mediated visual field coverage}

In Figure 3, pRFs measured from V1-V3 are plotted in visual space, with polar angle value indicated by colour, and pRF size indicated by circle size. In all participants, pRFs derived from rod-mediated retinotopic maps tiled the visual field systematically, as did cone-mediated pRFs from the control participant. In contrast, cone-mediated visual field coverage in patients was poor before treatment. The small areas of foveal coverage likely arise from the same fitting artefacts discussed above 
medRxiv preprint doi: https://doi.org/10.1101/2020.12.16.20246710; this version posted December 23, 2020. The copyright holder for this preprint (which was not certified by peer review) is the author/funder, who has granted medRxiv a license to display the preprint in It is made available under a CC-BY-NC-ND 4.0 International license .

(these disappear with increased goodness of fit; at $\mathrm{R}^{2}>0.05$ ). After treatment, visual field coverage had visibly increased in patient T2, but less so in patient T1. Population receptive field sizes derived from rod-mediated and cone-mediated mapping in patient T1 and T2 were large compared to those of control participants, particularly during pre-treatment measures (Supplementary Materials 4 Figure S4). Whilst preliminary, this is consistent with low visual acuity found in ACHM (Song et al., 2015), and, if replicated in a larger sample, may indicate that rod-mediated information processing in ACHM differs from that in normal sighted individuals.

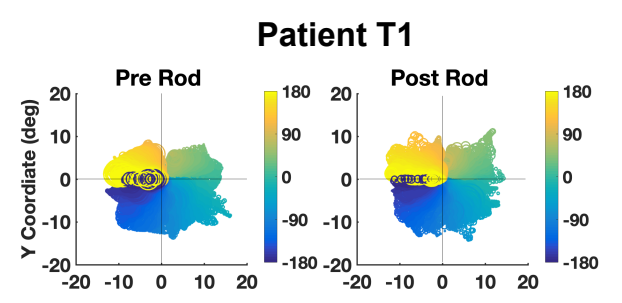

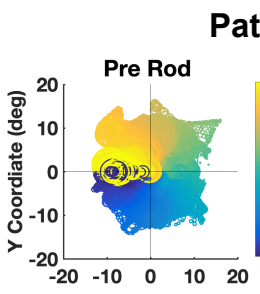

Patient T2
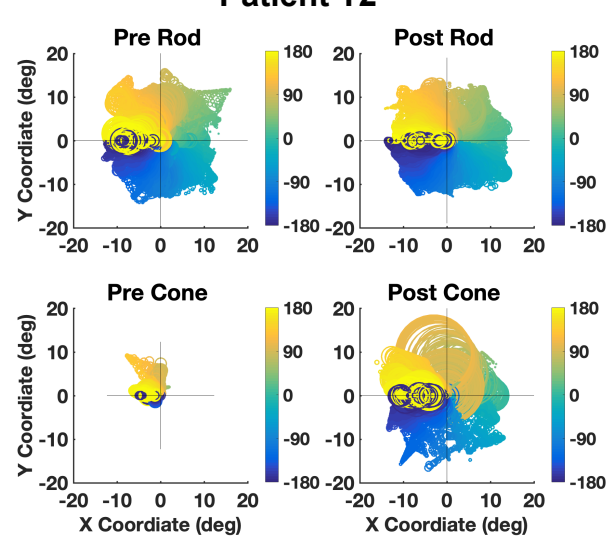

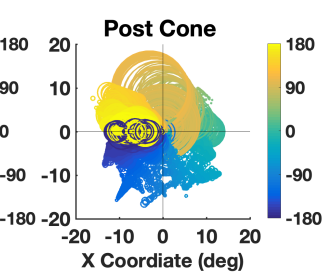

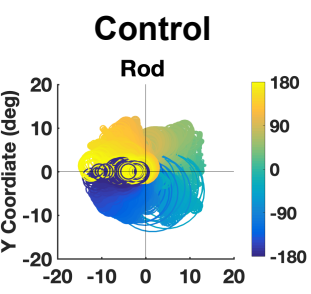

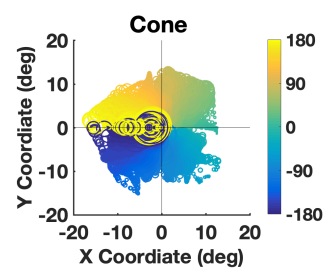

Figure 3. Visual field coverage before and after treatment for patient T1 and T2 and an age-matched control. Figures contain pRFs with unthresholded goodness of fit from V1, V2, and V3 extracted from the rod-mediated (top), and cone-mediated map (bottom) in left and right hemispheres. Colour indicates polar angle value. Circle size indicates receptive field size.

\section{fMRI Data Quality Control}

It is important to ensure that longitudinal fMRI measures are not confounded by head or eye movements, as both requirements can be challenging for young individuals with nystagmus. For both patients included in this study, head movement during scanning was minimal, with scan-to-scan movement remaining well below the $2.3 \mathrm{~mm}^{2}$ voxel size pre- and post-treatment (Supplementary Materials 5 Figure S5). To assess fixation stability, we examined performance on the central fixation task, and variance of horizontal eye movements. We report horizontal eye movement because this is the dominant direction of nystagmus, and because vertical eye movements were prone to blink-, eyelash, and scanner vibration artefacts (Supplementary Materials 6 Figure S6a). Task performance was high for both patients before and after treatment, as well as for the control participant (>95\% in all pRF-mapping runs). Whilst horizontal 
medRxiv preprint doi: https://doi.org/10.1101/2020.12.16.20246710; this version posted December 23,2020 . The copyright holder for this
preprint (which was not certified by peer review) is the author/funder, who has granted medRxiv a license to display the preprint in It is made available under a CC-BY-NC-ND 4.0 International license .

eye movement variance in patients was about twice that of the control participant, both $\mathrm{T} 1$ and T2 were able to control their nystagmus well when fixation was required, with the largest median standard deviation during an fMRI scan 0.27 degrees across all conditions, before and after treatment (Supplementary Materials 6 Table S6, Supplementary Materials 6 Figure S6b). These control analyses suggest that fMRI data were well-matched in quality across participants, scanning conditions, and time points, but do highlight the challenges of longitudinal fMRI with eye-tracking in children with low vision.

\section{Discussion}

Robust tests of visual function for children with inherited eye disease are essential for measuring the impact of new sight-rescuing therapies, particularly when treatment benefits are likely to be greater at young ages. Here we present a new multimodal approach that leverages a combination of psychophysics and fMRI to address this need. We demonstrate the use of this approach for linking behavioural measures of cone function to cone-mediated signals in the visual cortex of two children with ACHM, enrolled in gene therapy clinical trials targeting CNGA3 and CNGB3 associated ACHM.

The two patients presented here displayed no evidence of cone function across psychophysical and neural measures before the gene therapy intervention. They performed at chance when asked to detect chromatic-pair stimuli that selectively activate cone photoreceptors, and demonstrated no measurable cortical signal in response to these chromatic-pairs embedded in a pRF mapping stimulus. These pretreatment measures closely matched those of 10 other untreated patients with ACHM tested under identical circumstances. Cone-selective chromatic-pair stimuli that were invisible to all untreated patients with $\mathrm{ACHM}$, were easily visible to normal-sighted control individuals. Together, this shows our study correctly targeted cone-selective information processing channels.

Approximately 6 months after gene therapy, the cone-photoreceptor targeting stimuli remained invisible to patient T1 but had become discriminable to patient T2. Selective to the treated eye, patient T2 improved to ceiling level on psychophysical tests of cone contrast sensitivity, indicating that performance on this task now matched 
medRxiv preprint doi: https://doi.org/10.1101/2020.12.16.20246710; this version posted December 23, 2020. The copyright holder for this preprint (which was not certified by peer review) is the author/funder, who has granted medRxiv a license to display the preprint in It is made available under a CC-BY-NC-ND 4.0 International license

that of individuals with normal cone function. In addition, there was strong evidence for cone-driven signals in visual cortical areas V1-V3 of patient T2, which had been absent prior to treatment. Activation patterns in response to the cone-selective stimulus also showed clear retinotopic organisation, now resembling maps from 26 control adults and children with normal cone function. Given the highly organised nature of retinotopic responses in early visual cortex, it is most unlikely that these findings could have emerged from random noise fluctuations. Head- and eyemovements were measured throughout the pre- and post-treatment scan sessions and found to be comparable across conditions and time points. Therefore, the finding of a striking change in results observed in patient T2 after gene therapy, relative to patient $\mathrm{T} 1$, is highly unlikely to be driven by measurement confounds.

Whilst evidence for cone sensitivity clearly emerged after treatment in patient T2, cone-mediated fMRI measures remained less robust than those of controls. Because fMRI data was collected binocularly, this may in part stem from the restriction of treatment to the worse eye by trial protocol. In addition, however, whilst the lowest cone contrast in the cone-selective stimulus set was immediately visible to controls with normal cone function, patient T2 took longer to detect the location of the stimulus before giving their response, even with their untreated eye closed. Thus, while aspects of cone function improved after treatment, the impact on broader visual function remains to be explored. Incidentally, patient T2 reported seeing "different" with their treated eye, mentioning perceived benefits for reading certain signs. Patient T1 reported no clear difference in their perception after treatment, for either eye. Longitudinal data of the full dataset of treated children tested will be reported after trial completion.

Whilst preliminary, the present findings are in keeping with those of Fischer et al. (2020), in suggesting that in some cases, a degree of neural infrastructure for useful cone function may be preserved in ACHM after $>10$ years of age, beyond what are often considered the most sensitive periods for vision. This is in line with studies showing that in cases of bilateral congenital cataract, late removal of the affected lens has lasting effects on many visual function, but that some recovery is possible even if treatment occurs in adulthood (Maurer, 2017; McKyton et al., 2015). In the case of 
medRxiv preprint doi: https://doi.org/10.1101/2020.12.16.20246710; this version posted December 23, 2020. The copyright holder for this preprint (which was not certified by peer review) is the author/funder, who has granted medRxiv a license to display the preprint in It is made available under a CC-BY-NC-ND 4.0 International license .

ACHM, experience with rod-based vision likely scaffolds perceptual capacities that late recovered cone-mediated function may benefit from.

The multi-modal approach employed here, could provide useful insight in neural plasticity constraints beyond the retina itself, that successful ocular gene therapies must overcome. Cone photoreceptor activation normally helps refine neural connections from retina to cortex through experience-dependent competitive processes (Huberman et al., 2008; Kiorpes, 2019). With cone activation missing from gestation in $\mathrm{ACHM}$, enhanced competitive pressures from rod-dominated vision may alter the organization of visual pathways, and limit the scope for treatment efficacy. In line with this, one fMRI study reported that in three patients with ACHM, cortical areas that normally encode the foveal retina, which contains only cone receptors, were activated by more eccentric parts of the visual field that stimulate rod-containing retina (Baseler et al., 2002). This may indicate that rod-mediated signals can invade dormant cone-innervated cortex in ACHM. However, a similar shift in spatial tuning profile arises in normally sighted individuals from measurement artefacts at the edge of the rod scotoma (Barton \& Brewer, 2015). It is therefore still unclear if reorganisation of cone signalling pathways occurs in ACHM, and if so, how and when. Because the success of gene therapy may depend in part on the degree to which such reorganisation is present and reversible, it will be important to investigate pRF tuning in ACHM in the context of treatment outcomes.

A critical question to address in future, is what may explain individual differences in patients' vision after gene therapy. ACHM patients enrolled in gene therapy trials, including the age-matched example patients reported here, may differ on many variables, including retinal architecture, treatment dosage, genetic profile, and pre-existing retinal, post-retinal, and functional characteristics, which may vary with age. We anticipate that in future, the fine-grained information obtained with fMRI combined with psychophysical measures of cone function, will help elucidate how these genetic, neural, developmental, and treatment factors, interact to shape visual function in patients with ACHM.

We conclude that the combined psychophysical and fMRI findings provide unequivocal evidence for individual differences in the improvement of cone function 
medRxiv preprint doi: https://doi.org/10.1101/2020.12.16.20246710; this version posted December 23,2020 . The copyright holder for this preprint (which was not certified by peer review) is the author/funder, who has granted medRxiv a license to display the preprint in

after gene therapy in children with $\mathrm{ACHM}$. This demonstrates that the multi-modal approach presented here is feasible for use in children with low vision and shows significant potential for the sensitive tracking of paediatric ocular gene therapy outcomes at an individual level. To understand the generalisability of these results to other patients, these findings will need to be further extended in a larger cohort, of a broader age range, assessed over a longer time period.

\section{Acknowledgments / Funding}

The research was supported by grants from the National Institute for Health Research (NIHR) Biomedical Research Centre based at Moorfields Eye Hospital NHS Foundation Trust and UCL Institute of Ophthalmology, the European Social Research Council (\#ES/N000838/1); MeiraGTx, Retina UK, Moorfields Eye Hospital Special Trustees, Moorfields Eye Charity (R160035A, R190029A, R180004A), Foundation Fighting Blindness (USA) and The Wellcome Trust (099173/Z/12/Z, 100227), Ardalan Family Scholarship, the Persia Educational Foundation Maryam Mirzakhani Scholarship; and the Sir Richard Stapley Educational Trust (\#313812). The views expressed are those of the authors and not necessarily those of the NHS, the NIHR, or the Department of Health. 
medRxiv preprint doi: https://doi.org/10.1101/2020.12.16.20246710; this version posted December 23,2020 . The copyright holder for this
preprint (which was not certified by peer review) is the author/funder, who has granted medRxiv a license to display the preprint in

\section{Methods}

\section{Participants}

As the gene therapy trial and data collection are still ongoing, with treatment conditions and outcomes yet to be disclosed, we present interim measures from 2 paediatric patients who represent the range of results observed so far. The patients (patient T1 and T2, with CNGB3 and CNGA3 variants respectively), were over 9 years old at the time of first visit. Both were tested twice, once before, and $\sim 6$ months after treatment. These two cases are presented in the context of MRI and psychophysics measures from 11 untreated children (Mean Age $=11.27$, Range $=8-15$ years, $S D=$ 2.49) and 2 adults (25 and 27 years) all with genetically confirmed CNGA3 or CNGB3associated $\mathrm{ACHM}$, and data from 28 normal-sighted age-matched controls (16 children: Mean Age = 10.62, Range = 6-14 years, SD = 2.60; 12 adults: Mean Age = 24.42 , Range $=18-34$ years, $S D=4.42)$ tested once under identical circumstances. Data from one of these untreated children with ACHM was excluded due to low quality. For two control participants (aged $<7$ years) the rod-mediated pRF map was not collected in order to keep testing length age-appropriate. All participants met MRI safety inclusion criteria and had no known neurological disorders besides, in patients, ACHM. Informed consent was obtained from all parents before taking part, and children themselves gave informed assent. Patients were enrolled in clinical trials NCT03758404 and NCT03001310. Data collection for this MRI study had stand-alone ethics approval, from the national ethics committee for patients (\#MICM1007) and the UCL ethics committee for normal sighted control participants (\#4846/001).

\section{Apparatus}

We used a Siemens Avanto 1.5T MRI scanner and a 30-channel coil (a 32channel coil customised to remove view obstructions) to acquire structural and functional MRI data. Stimuli were presented on an MR-compatible LCD display (BOLDscreen 24, Cambridge Research Systems Ltd., UK; 51 x 32 cm; 1920 x 1200 pixels) viewed through a mirror in the scanner at $105 \mathrm{~cm}$ distance. Participants were lying supine in the scanner, with fixation stability recorded where possible via a mirror, with an Eyelink 1000 at the back of bore. Behavioural psychophysics was also performed in the scanner room, after scanning, under similar viewing circumstances as the functional MRI data collection. 
medRxiv preprint doi: https://doi.org/10.1101/2020.12.16.20246710; this version posted December 23, 2020. The copyright holder for this preprint (which was not certified by peer review) is the author/funder, who has granted medRxiv a license to display the preprint in It is made available under a CC-BY-NC-ND 4.0 International license .

\section{Cone-selective stimuli in psychophysics and functional MRI}

To measure cone-mediated signal processing, we used the silent substitution approach to generate pairs of chromatic stimuli designed to selectively activate L- and M-cones whilst keeping rod activation constant (for details, see Estevez \& Spekreijse, 1982; and Spitschan \& Woelders, 2018). In brief, we computed transformation matrices to convert changes in the LCD screen's red, green, and blue channel (RGB) voltages, into changes in L-cone, M-cone and rod photoreceptor stimulation, using measures of the screen's RGB spectral outputs (made with a Spectrascan Spectroradiometer, PR-655, PhotoResearch Inc.) and the standard observer sensitivity functions for rod and cone photoreceptors (Stockman \& Sharpe, 2000; Wyszecki \& Stiles, 1982). This allowed us to calculate the change in RGB voltage required to independently increment or decrement L- and M-cone or rod photoreceptor activity by pre-specified proportions with respect to a baseline RGB value (mid-grey). We used this approach to generate chromatic-pairs that varied L- and M-cone photoreceptor activation whilst leaving rod photoreceptor activation constant. For these stimuli we required to silence only one type of photoreceptor (rods) rather than two, giving more freedom in the colour directions we chose. To account for any imperfect matching of rod activation (e.g., due to light measurement and correction errors, variations in rod sensitivity, or screen inhomogeneity), we kept the blue voltage constant (rods are relatively much more sensitive to the blue channel than the L- or M-cones are) and only varied the $R$ and $G$ channels, thus shifting the stimulus variations towards longer wavelengths where rods are less sensitive and errors in rod equating are likely to be small. See Supplementary Materials 1 for validation measures. Neutral density filters were used to present these stimuli in the mesopic/low photopic light range $\left(0.6-1.3 \mathrm{~cd} / \mathrm{m}^{2}\right.$ for psychophysics, $0.8 \mathrm{~cd} / \mathrm{m}^{2}$ for $\left.\mathrm{fMRI}\right)$, whilst keeping viewing comfortable for photosensitive patients.

\section{Rod-selective stimuli in functional MRI}

Rod-selective stimuli, only used in the MRI scanner, were obtained using a similar approach. We used silent substitution to generate a chromatic pair that kept $\mathrm{L}$ and $\mathrm{M}$ contrast constant, but induced a contrasting response in rods. With 3 colour 
medRxiv preprint doi: https://doi.org/10.1101/2020.12.16.20246710; this version posted December 23,2020 . The copyright holder for this
preprint (which was not certified by peer review) is the author/funder, who has granted medRxiv a license to display the preprint in

channels it is only possible to simultaneously silence two photoreceptor types, and the resulting stimulus was not controlled for S-cone contribution. Therefore, to reduce the S-cone response, we presented these stimuli at a much lower light level $\left(0.02 \mathrm{~cd} / \mathrm{m}^{2}\right)$. However, we cannot exclude the possibility that functioning cone photoreceptors may have been activated under these circumstances and contributed to the rod-mediated maps in individuals with S-cone function (for further details and validation measures, see Supplementary Materials 2).

\section{Behavioural Psychophysics}

Each participant performed 2 psychophysical tests:

1) $4 A F C$ localisation task: participants located a chromatic patch that induced a high $L$ and $M$ response (subtending $3^{\circ}$ of visual angle) against a chromatic background that induced a low $L$ and $M$ response. The patch was presented at $6^{\circ}$ eccentricity either left, right, above or below a central marker $\left(0.4^{\circ} \mathrm{VA}\right)$ (Figure $\left.1 \mathrm{~A}\right)$. Participants were not required to fixate and had unlimited time to search. The cone contrast between target patch and background decreased gradually, following a 4-AFC 1-up/1-down staircase. Each adaptive staircase continued until at least 14 reversals had occurred (mean $\mathrm{N}$ trials $=27$ ).

2) $2 A F C$ movement discrimination task: to assess the validity of these measures with the pRF stimulus, the cone contrast sensitivity threshold was also measured in a 2AFC task with the cone-selective ring-and-wedge fMRI stimulus (Figure 1B). Participants detected movement of a checkerboard ring (inward/outward) or wedge (clockwise/anti-clockwise), reversing at $2 \mathrm{~Hz}$, in a 1-up/1-down staircase (converging at chancel level) until at least 8 reversals had occurred (mean $\mathrm{N}$ trials $=25$ ).

\section{pRF mapping fMRI}

Inside the scanner, participants first practised lying still whilst watching a cartoon that was paused whenever the researcher observed excessive headmovement via a face camera. Throughout each acquisition session, patients were constantly monitored for any signs of discomfort or movement via various cameras and a 2-way intercom. pRF mapping stimuli comprised of a simultaneous rotating ring and contracting/expanding wedge, each made up of cone- or rod- selective chromaticpairs, embedded within a contrast-reversing checkerboard with $2 \mathrm{~Hz}$ reversal rate 
medRxiv preprint doi: https://doi.org/10.1101/2020.12.16.20246710; this version posted December 23, 2020. The copyright holder for this preprint (which was not certified by peer review) is the author/funder, who has granted medRxiv a license to display the preprint in It is made available under a CC-BY-NC-ND 4.0 International license .

(Figure 1B). Per run, the ring expanded/contracted for 6 cycles (48 secs/cycle) with logarithmic eccentricity scaling (van Dijk et al., 2016). The wedge (20 VA angle) rotated clockwise/anticlockwise for 8 cycles (36 sec/cycle). 20-second fixation baselines were embedded at the start, at the mid-point, and end of the run (total run duration 348 secs). The stimuli covered a maximum eccentricity of $8.6^{\circ}$, and moved to a new position each 1-second TR. The stimulus was overlaid with a small white central fixation dot $\left(0.2^{\circ} \mathrm{VA}\right.$ radius) and a black radial grid to encourage stable fixation. Participants completed 6 pRF mapping runs in total: 2 with cone-selective stimuli, 2 with rod-selective stimuli, and 2 with non-selective stimuli (i.e., standard luminance contrast-reversing checkerboard) used for delineation of cortical visual areas. Highresolution structural scans were obtained during a 15-minute dark adaptation phase, during which participants listened to an audiobook. The order of runs was pre-set and identical for each participant: 2 rod-selective, 2 cone-selective, 2 non-selective (luminance contrast) runs.

During the pRF mapping scans, participants indicated by button press when they detected fixation target change from white to black. This task was presented as a rewarded "kitten rescue mission game" to promote engagement. Children reported to enjoy this game and seeing their own brain afterwards and were happy to play again in a next visit. Built-in calibration of the eye-tracker to quantify fixation stability, was not possible due to nystagmus. We therefore calibrated the camera in advance on a healthy eye, and for every other run we asked the patients to fixate on a 5-point custom calibration, used to calibrate eye-gaze measures post-hoc (see supplementary materials 5).

\section{MRI sequences}

Functional T2*-weighted multiband 2D echo-planar images (Setsompop et al., 2012) were collected using a multi-band 28 sequence (TR $=1 \mathrm{~ms}, \mathrm{TE}=55 \mathrm{~ms}$, slices $=348$, flip angle $=75^{\circ}$, acceleration $=4$ ) with a resolution of $2.3 \mathrm{~mm}$ isotropic voxels. A high-resolution structural scan was acquired using a T1-weighted 3D MPRAGE (1 $\mathrm{mm}^{3}$ voxel size, Bandwidth $=190 \mathrm{~Hz} /$ pix, 176 partitions, partition TR $=2730, \mathrm{TR}=$ $8.4 \mathrm{~ms}, \mathrm{TE}=3.57$, effective $\mathrm{T} 1=1000 \mathrm{~ms}$, flip angle $=7$ degrees $)$. A lower-resolution MPRAGE was also obtained in the same orientation as the multiband sequence to aid co-registration between functional and structural images. 
medRxiv preprint doi: https://doi.org/10.1101/2020.12.16.20246710; this version posted December 23, 2020. The copyright holder for this preprint (which was not certified by peer review) is the author/funder, who has granted medRxiv a license to display the preprint in It is made available under a CC-BY-NC-ND 4.0 International license .

MRI Data analysis

All functional data were pre-processed using SPM12 (http://www.fil.ion.ucl.ac.uk/spm). Functional volumes were realigned to the first image of each run to correct for head movement. All functional scans (collected pre- and post-treatment) were then aligned to the high-resolution structural scan collected pretreatment. For accuracy, a low-resolution structural image with the same orientation as the functional volumes was used as an intermediate step to compute the coregistration matrix. FreeSurfer software (v5.3.0 with XQuartz v2.7.8,https://surfer.nmr.mgh.harvard.edu/) was used to construct 3D surface meshes for the right and left cortical hemispheres (Fischl et al., 1999), using the recon-all pipeline. Any holes or edges were corrected manually using FreeSurfer Freeview tool. Pre-processed functional data were projected onto the surface using the MATLAB toolbox 'SamSrf' v5.84 (http://dx.doi.org/10.6084/m9.figshare.1344765) for further analyses.

To model population receptive fields, we used a symmetric bivariate Gaussian model, with mean $(\mathrm{x}, \mathrm{y})$ representing the preferred retinotopic location, and standard deviation $(\sigma)$ representing $\mathrm{pRF}$ size. To identify the $\operatorname{RF}$ model $(x, y, \sigma)$ that best predicts the measured time series, a two-stage fitting procedure was employed. In a coarse fitting step, data was smoothed along the cortical surface (Gaussian kernel fwhm $=5 \mathrm{~mm}$ ), and a grid-search approach was used to identify model parameters that maximise the Pearson correlation between observed data and the pRF model's predicted time course. Vertices with a good fit $\left(R^{2}>0.05\right)$ were entered as starting value in a fine-fitting step, in which Matlab's fminsearch function was used to identify parameters that minimised the squared residual deviations between the model and unsmoothed data. Finally, best-fitting parameters were smoothed along the surface (fwhm $=3 \mathrm{~mm}$ ), and $X$ and $Y$ position estimates were converted to eccentricity (distance from fixation) and polar angle.

\section{Regions of Interest}

Visual regions were delineated manually by displaying the polar-angle map generated using by the non-selective pRF mapping stimulus on the inflated cortical 
medRxiv preprint doi: https://doi.org/10.1101/2020.12.16.20246710; this version posted December 23, 2020. The copyright holder for this preprint (which was not certified by peer review) is the author/funder, who has granted medRxiv a license to display the preprint in It is made available under a CC-BY-NC-ND 4.0 International license .

surface for each individual. Standard criteria were used to identify the borders between V1, V2 \& V3 (Deyoe et al., 1996; Engel et al., 1997; Sereno et al., 1995).

\section{References}

Aboshiha, J., Dubis, A. M., Cowing, J., Fahy, R. T. A., Sundaram, V., Bainbridge, J. W., Ali, R. R., Dubra, A., Nardini, M., Webster, A. R., Moore, A. T., Rubin, G., Carroll, J., \& Michaelides, M. (2014). A prospective longitudinal study of retinal structure and function in achromatopsia. Investigative Ophthalmology and Visual Science, 55(9), 5733-5743. https://doi.org/10.1167/iovs.14-14937

Barton, B., \& Brewer, A. A. (2015). fMRI of the rod scotoma elucidates cortical rod pathways and implications for lesion measurements. PNAS, 112(16), 52015206. https://doi.org/10.1073/pnas.1423673112

Baseler, H. A., Brewer, A. A., Sharpe, L. T., Morland, A. B., Jaägle, H., \& Wandell, B. A. (2002). Reorganization of human cortical maps caused by inherited photoreceptor abnormalities. Nature Neuroscience, 5(4), 364-370.

https://doi.org/10.1038/nn817

Burnham, K. P. \& Anderson, D. R. (2002). Model Selection and Multimodel Inference: A Practical Information-Theoretic Approach. Springer New York, 2002.

Ciulla, T. A., Hussain, R. M., Berrocal, A. M., \& Nagiel, A. (2020). Voretigene Neparvovec-rzyl for Treatment of RPE65 -Mediated Inherited Retinal Diseases: A Model for Ocular Gene Therapy Development. Expert Opinion on Biological Therapy, 14712598.2020.1740676.

https://doi.org/10.1080/14712598.2020.1740676

Clavagnier, S., Dumoulin, S. O., \& Hess, R. F. (2015). Is the cortical deficit in amblyopia due to reduced cortical magnification, loss of neural resolution, or neural disorganization? Journal of Neuroscience, 35(44), 14740-14755. https://doi.org/10.1523/JNEUROSCI.1101-15.2015

Deyoe, E. A., Carman, G. J., Bandettini, P., Glickman, S., Wieser, J., Cox, R., Miller, D., \& Neitz, J. (1996). Mapping striate and extrastriate visual areas in human cerebral cortex. Proceedings of the National Academy of Sciences of the United States of America, 93(6), 2382-2386. https://doi.org/10.1073/pnas.93.6.2382

Dubis, A. M., Cooper, R. F., Aboshiha, J., Langlo, C. S., Sundaram, V., Liu, B., Collison, F., Fishman, G. A., Moore, A. T., Webster, A. R., Dubra, A., Carroll, J., \& Michaelides, M. (2014). Genotype-dependent variability in residual cone 
medRxiv preprint doi: https://doi.org/10.1101/2020.12.16.20246710; this version posted December 23, 2020. The copyright holder for this preprint (which was not certified by peer review) is the author/funder, who has granted medRxiv a license to display the preprint in It is made available under a CC-BY-NC-ND 4.0 International license .

structure in achromatopsia: Toward developing metrics for assessing cone health. Investigative Ophthalmology and Visual Science, 55(11), 7303-7311. https://doi.org/10.1167/iovs.14-14225

Dunn, M. J., Harris, C. M., Ennis, F. A., Margrain, T. H., Woodhouse, J. M., Mcllreavy, L., \& Erichsen, J. T. (2019). An automated segmentation approach to calibrating infantile nystagmus waveforms. Behavior Research Methods, 51(5), 2074-2084. https://doi.org/10.3758/s13428-018-1178-5

Engel, S. A., Glover, G. H., \& Wandell, B. A. (1997). Retinotopic organization in human visual cortex and the spatial precision of functional MRI. Cerebral Cortex, 7(2), 181-192. https://doi.org/10.1093/cercor/7.2.181

Estévez, O., \& Spekreijse, H. (1982). The "silent substitution" method in visual research. Vision Research, 22(6), 681-691. https://doi.org/10.1016/00426989(82)90104-3

Fischer, M. D., Michalakis, S., Wilhelm, B., Zobor, D., Muehlfriedel, R., Kohl, S., Weisschuh, N., Ochakovski, G. A., Klein, R., Schoen, C., Sothilingam, V., Garcia-Garrido, M., Kuehlewein, L., Kahle, N., Werner, A., Dauletbekov, D., Paquet-Durand, F., Tsang, S., Martus, P., ... Wissinger, B. (2020). Safety and Vision Outcomes of Subretinal Gene Therapy Targeting Cone Photoreceptors in Achromatopsia: A Nonrandomized Controlled Trial. JAMA Ophthalmology, 138(6), 643-651. https://doi.org/10.1001/jamaophthalmol.2020.1032

Fischl, B., Sereno, M. I., \& Dale, a M. (1999). Cortical surface-based analysis. II: Inflation, flattening, and a surface-based coordinate system. Neurolmage, 9(2), 195-207. https://doi.org/10.1006/nimg.1998.0396

Georgiou, M., Litts, K. M., Kalitzeos, A., Langlo, C. S., Kane, T., Singh, N., Kassilian, M., Hirji, N., Kumaran, N., Dubra, A., Carroll, J., \& Michaelides, M. (2019). Adaptive optics retinal imaging in CNGA3-associated achromatopsia: Retinal characterization, interocular symmetry, and intrafamilial variability. Investigative Ophthalmology and Visual Science, 60(1), 383-396.

https://doi.org/10.1167/iovs.18-25880

Hirji, N., Aboshiha, J., Georgiou, M., Bainbridge, J., \& Michaelides, M. (2018).

Achromatopsia: clinical features, molecular genetics, animal models and therapeutic options. In Ophthalmic Genetics (Vol. 39, Issue 2, pp. 149-157).

Taylor and Francis Ltd. https://doi.org/10.1080/13816810.2017.1418389 Hirji, N., Georgiou, M., Kalitzeos, A., Bainbridge, J. W., Kumaran, N., Aboshiha, J., 
medRxiv preprint doi: https://doi.org/10.1101/2020.12.16.20246710; this version posted December 23, 2020. The copyright holder for this preprint (which was not certified by peer review) is the author/funder, who has granted medRxiv a license to display the preprint in It is made available under a CC-BY-NC-ND 4.0 International license .

Carroll, J., \& Michaelides, M. (2018). Longitudinal assessment of retinal structure in achromatopsia patients with long-term follow-up. Investigative Ophthalmology and Visual Science, 59(15), 5735-5744.

https://doi.org/10.1167/iovs.18-25452

Holmes, J. M., Lazar, E. L., Melia, B. M., Astle, W. F., Dagi, L. R., Donahue, S. P., Frazier, M. G., Hertle, R. W., Repka, M. X., Quinn, G. E., \& Weise, K. K. (2011). Effect of age on response to amblyopia treatment in children. In Archives of Ophthalmology (Vol. 129, Issue 11, pp. 1451-1457). American Medical Association. https://doi.org/10.1001/archophthalmol.2011.179

Huberman, A. D., Feller, M. B., \& Chapman, B. (2008). Mechanisms underlying development of visual maps and receptive fields. In Annual Review of Neuroscience (Vol. 31, pp. 479-509). NIH Public Access.

https://doi.org/10.1146/annurev.neuro.31.060407.125533

Johnson, S., Michaelides, M., Aligianis, I. A., Ainsworth, J. R., Mollon, J. D., Maher, E. R., Moore, A. T., \& Hunt, D. M. (2004). Achromatopsia caused by novel mutations in both CNGA3 and CNGB3. Journal of Medical Genetics, 41(2), 20. https://doi.org/10.1136/jmg.2003.011437

Kiorpes, L. (2019). Understanding the development of amblyopia using macaque monkey models. Proceedings of the National Academy of Sciences of the United States of America, 116(52), 26217-26223.

https://doi.org/10.1073/pnas.1902285116

Kohl, S., Varsanyi, B., Antunes, G. A., Baumann, B., Hoyng, C. B., Jägle, H., Rosenberg, T., Kellner, U., Lorenz, B., Salati, R., Jurklies, B., Farkas, A., Andreasson, S., Weleber, R. G., Jacobson, S. G., Rudolph, G., Castellan, C., Dollfus, H., Legius, E., ... Wissinger, B. (2005). CNGB3 mutations account for $50 \%$ of all cases with autosomal recessive achromatopsia. European Journal of Human Genetics, 13(3), 302-308. https://doi.org/10.1038/sj.ejhg.5201269 Maurer, D. (2017). Critical periods re-examined: Evidence from children treated for dense cataracts. In Cognitive Development (Vol. 42, pp. 27-36). Elsevier Ltd. https://doi.org/10.1016/j.cogdev.2017.02.006

McKyton, A., Ben-Zion, I., Doron, R., \& Zohary, E. (2015). The Limits of Shape

Recognition following Late Emergence from Blindness. Current Biology, 25(18), 2373-2378. https://doi.org/10.1016/j.cub.2015.06.040

Pewsey, A., Neuhäuser, M., \& Ruxton, G. (2013). Circular statistics in R. 
medRxiv preprint doi: https://doi.org/10.1101/2020.12.16.20246710; this version posted December 23, 2020. The copyright holder for this preprint (which was not certified by peer review) is the author/funder, who has granted medRxiv a license to display the preprint in It is made available under a CC-BY-NC-ND 4.0 International license .

https://books.google.com/books?hl=en\&lr=\&id=qeadAAAAQBAJ\&oi=fnd\&pg=PP 1\&dq=Pewsey, + A. ,+Neuhäuser,+M.,+\%26+Ruxton, + +G.+D.+(2013) .+Circular+st atistics+in+R.+Oxford+University+Press.\&ots=eiGh_9vxlb\&sig=VkjPMonDKSjw ZMeDQpYUaCF8EDY

Rosengren, W., Nyström, M., Hammar, B., \& Stridh, M. (2020). A robust method for calibration of eye tracking data recorded during nystagmus. Behavior Research Methods, 52(1), 36-50. https://doi.org/10.3758/s13428-019-01199-0

Sereno, M. I., Dale, A. M., Reppas, J. B., Kwong, K. K., Belliveau, J. W., Brady, T. J., Rosen, B. R., \& Tootell, R. B. H. (1995). Borders of multiple visual areas in humans revealed by functional magnetic resonance imaging. Science, 268(5212), 889-893. https://doi.org/10.1126/science.7754376

Setsompop, K., Gagoski, B. A., Polimeni, J. R., Witzel, T., Wedeen, V. J., \& Wald, L.

L. (2012). Blipped-controlled aliasing in parallel imaging for simultaneous multislice echo planar imaging with reduced $g$-factor penalty. Magnetic Resonance in Medicine, 67(5), 1210-1224. https://doi.org/10.1002/mrm.23097

Song, C., Schwarzkopf, D. S., Kanai, R., \& Rees, G. (2015). Neural population tuning links visual cortical anatomy to human visual perception. Neuron, 85(3), 641-656. https://doi.org/10.1016/j.neuron.2014.12.041

Spitschan, M., \& Woelders, T. (2018). The Method of Silent Substitution for

Examining Melanopsin Contributions to Pupil Control. Frontiers in Neurology, 9(NOV), 941. https://doi.org/10.3389/fneur.2018.00941

Stockman, A., \& Sharpe, L. T. (2000). The spectral sensitivities of the middle- and long-wavelength-sensitive cones derived from measurements in observers of known genotype. Vision Research, 40(13), 1711-1737.

https://doi.org/10.1016/S0042-6989(00)00021-3

Tailor, V. K., Theodorou, M., Dahlmann-Noor, A. H., \& Greenwood, J. A. (2020). The effect of eye movements on visual crowding in congenital nystagmus. Journal of Vision, 20(11), 711. https://doi.org/10.1167/jov.20.11.711

van Dijk, J. A., de Haas, B., Moutsiana, C., \& Schwarzkopf, D. S. (2016).

Intersession reliability of population receptive field estimates. Neurolmage, 143, 293-303. https://doi.org/10.1016/j.neuroimage.2016.09.013

Wagenmakers, E.-J., Farrell, S., \& Wagenmakers, -J. (2004). AlC model selection using Akaike weights.

Wyszecki, G., \& Stiles, W. (1982). Color science. 
medRxiv preprint doi: https://doi.org/10.1101/2020.12.16.20246710; this version posted December 23, 2020. The copyright holder for this preprint (which was not certified by peer review) is the author/funder, who has granted medRxiv a license to display the preprint in It is made available under a CC-BY-NC-ND 4.0 International license

https://www.academia.edu/download/36909884/Color_Science.pdf 